\title{
Building a Vibrant State-Civil Society in Cameroon Facing the Changes of the New Millenium
}

John W. Forje

\section{(2) OpenEdition \\ Journals}

Electronic version

URL: http://journals.openedition.org/apad/461

DOI: 10.4000/apad.461

ISSN: 1950-6929

Publisher

LIT Verlag

\section{Printed version}

Date of publication: 15 December 1999

\section{Electronic reference}

John W. Forje, « Building a Vibrant State-Civil Society in Cameroon Facing the Changes of the New Millenium », Bulletin de l'APAD [Online], 18| 1999, Online since 20 September 2006, connection on 21 December 2020. URL : http://journals.openedition.org/apad/461 ; DOI : https://doi.org/10.4000/apad 461

This text was automatically generated on 21 December 2020.

Bulletin de l'APAD 


\section{Building a Vibrant State-Civil Society in Cameroon Facing the Changes of the New Millenium}

John W. Forje

1 The author acknowledges with profound thanks the assistance given by John Suh Che and Chief F. Fotem of the Cameroonian Ministry of Scientific and Technical Research.

A country in disarray

2 The economic and political performance of Cameroon during the past two decades has been generally poor. Per capital food production has remained in an extremely discouraging state even though Cameroon remains the bread basket for countries within the central African Sub-region. Poverty is on the increase where more than 50\% of the population are classified as "poor country" following the 1999 United Nations Development Programme (UNDP), Report for Cameroon. The population growth rate stands at over $2.8 \%$ (Forje forthcoming). Corruption and mismanagement are on the increase with Cameroon receiving the honour or dishonour of the first position as the most corrupt nation in the world according to the Transparency International Findings. The country's human rights record is deplorable, and transition towards genuine democratisation transition following the second wave of political changes blowing across the continent and the rest of the developing world is not a good one. Civic associations are viewed by the state as enemies. Whereas state and civic association accord should be treated as complimentary bodies and partners in the development process. They should not be apart but parts of the common struggle for the socio-economic and technological transformation of the society. The banking sector is in total shambles as over ten banks have wounded up during the past decade. There is a total lost of confidence in the financial sector and the government in general. General production is low with the exception of the increase in the brewery sector. Cameroon is an alcoholic consuming nation as every other house is a drinking bar. Over five different new brands of beer have been introduced into the market within the last year. Cameroonians find peace with the cup. The disadvantage is that it blurs their 
perception, line of action and attitude towards change. This works favourably to the advantage of the ruling regime.

There is a general drop in the standard of living - the result of two salary cuts amounting to $70 \%$ in 1993 and 1994 : a hundred percent devaluation of the CFA franc in 1994 ; two months of unpaid salaries to civil servants in 1993 ; and the general increase in the debt burden, external and internal. All these factors add to the plight of the Cameroonian population who today is considered the most devalued human beings within the continent. The sad fact is the non-existing of price control system and consumer's association to defend the rights of the consumers. Petrol sells at $425 \mathrm{CFA}$ francs per liter.

However, one good record, is that peace before the storm reigns in the country, even though insecurity to human life and property is in the increase. Though the country has come a long way from the horrific era of the single-party system, much remains to be done to attain genuine democratic governance and good management. So far, the transition to political pluralism has been plagued by electoral fraud and stolen victories by the incumbent regime sitting tight in spite of the lost of credibility and legitimacy amongst the people. The victory and power of the ballot box has never been respected and valued in the country. This thwarts the political dimensions on which depends the socio-economic, technologically transformation and development of the society.

5 Though rich in natural resources and human potentials, for almost two decades, the country once overwhelmed by economic growth miracle, the African style, is now constrained by debt burden, economic stagnation, corruption and mismanagement. The 1990s is groping with the paradox of civil strife, increasing abject poverty and misery boldly carved in gold on the faces of the vast majority of the population. This is backed with a complex transition process to democracy and liberal economic setting. Generally, one can state that the country though pulling towards the practice of multi-party democracy, (thanks perhaps to the collapse of the Berling Wall) on the one hand, and economic disintegration on the other - the result of out right embezzlement of government funds and the misuse of natural resources through the forces of an external unsustainable exploitation - Cameroon remains a nation with vast potentials capable of bundling itself out of the present economic, political chaos and malaise that confronts many African nations.

6 So far, there is the poor record of government performance, i.e. the transfer of authority and resources to capitalist institution. Even the best managed state enterprises (the Cameroon Development Corporation (CDC)), for example is up for sale. It is the French economic industrial complexes and interests that eventually will be the beneficiaries in the take-over of state enterprises in the country.

7 Reducing the role of the state via the mechanisms of privatisation and simply getting the price right alongside other macro-policies have proven insufficient to put development on the right course. Presently, one can at best develop an attitude of wait and see the outcomes of the ongoing privatisation process which seems to have taken off the ground from a bad perspective. The outcome is that insistence on privatisation measures by external bodies helps to place resources cheaply for the exploiters with the consequences of a deepening of the declining situation of the country's economic. This is reflected in Cameroon's increasing reliance on foreign grants and loans which have increased the debt burden and the dependency of the country. Because of the 
devaluation of the CFA franc, Cameroon is depleting its natural resources for less the amount obtained a few years back.

The role of the international community has been the formula prescription of the Bretton Woods Financial Institutions through the policy strategy of Structural Adjustment Programmes (SAP). Yet the new prescription offered by Western financial institutions to ameliorate existing conditions has turn out to be a curse rather than a blessing, hence SAP is better known as Structural or Social Added Problems in view of its impacted social and economic consequences on the vast majority of the marginalized population. The rural population and poor are paying the price for World Bank/IMF imposed structural approaches which only enriches the rich.

In short, the dictates of the Bretton Woods Institution in compliance with the ganging up or unholy alliance with the ruling elites, political power brokers and other stake holders within Cameroon continue to have a profound impact on the country's fragile and vulnerable political economy - an impact that is likely to be extended an exponential rather than short and specific impact as the country embraces the mythical decade 2000.

Hence, any contemporary debate on Cameroon must put into context the post-Cold War realities, the so-called new world order, the renewed international division of labour and power, without of course, by passing existing internal constraints particularly that of ethnic hegemonic politics, authoritarianism, the support of the military and, not least, the strong adherence to the inherent role of the single-party system as the only path to governance no matter the cost to the nation. The distinctive features of Cameroon in an era of national adjustment and global transformation need to be recognised and incorporated into both examination and prescription.

11 This paper attempts to address issues from that perspective and as well as advances pro active strategic policy measures that can better put Cameroon on a solid and productive footing to democratic governance and good management at the dawn of a new millennium. It surveys the major political, economic, social, ecological and gender-related aspects of Cameroon's struggle or no struggle towards democracy in the 1990s and beyond.

It builds on two fundamentally sets of ideas ; first the internal equilibrium which can be restored only through institutional changes, and, secondly, the role of the international community. Internally also are the broader issues of the subjects of women marginalization and environmental degradation, and how the political economy of the country has played havoc with, and the causes of the problems related to these issues.

Although both civil society and political economy are in transition, it would be erroneous to impose extra Cameroon perceptions, prescriptions and expectations. Yet it is necessary that certain guidelines be taken into serious consideration, otherwise, the country has no future and no framework on which to build a sustainable society.

Societal collapse in Cameroon cannot be treated only as a function of "strategic" issues based on statist assumptions that emphasised great powers rivalry on the resources of country, but also must include and prioritise a range of new forces of gender and population, ecology and environment, food and nutrition, shelter and health, conflict over natural resources and the greater ethnic and political divide confronting and constraining integrated sustainable development within the society. 
The combination of economic, political and ecological crisis beginning in the 1980s has contributed to a new policy and political context, many people now accept and advocate the practice of political pluralism, transparency, accountability as the best options for moving the country forward and in the right path.

Civil society and democratic transition

Leslie Fox notes that "civil society is a political concept because it is essentially about power, the power of non-state actors to participate in making decisions that have an impact on them". The failure of the nation-state as a liberator of its people but playing the role as an oppressor of the inalienable rights of its citizens and backed with the collapse of the communist system, triggered a new wave of political democratisation process in the 1990s that equally witnessed a marked reorientation of both academic and political discourse on development. Civil society was entrusted with a vibrant weapon once taken away by the institutionalisation of the dominant monolithic party structure.

The fall of the Berlin Wall engineered a new path to constructing a "political culture" in the developing regions of the world. In the case of Cameroon, the top-down approach institutionalised through the single-party proved that development does not work in that pattern; of the state remaining for long the rational instrument for promoting and controlling change in the direction of providing quality living standards for the vast majority of the population. : rather it had increased affluence for a selected few. The state of growing influence and affluence of the few eroded the ability of the State to be such a powerful instrument - had been replaced by growing disillusionment. From both the leftist and rightist perspectives, the Cameroon State was viewed as an instrument of exploitation, pre-empting popular or individual initiative and revolt as well as fanning discriminative politics of ethnic confrontation and economic chaos. Thus civil society in Cameroon remained passive or captive and weak from $1^{\text {st }}$ September 1966 to 26 May 1990.

8 Political parties and civic associations were co-opted or coerced into a single-party structure - The Cameroon Nation Union (CND) later transformed into Cameroon Peoples Democratic Movement (CPDM) until the launching of the Social Democratic Front (SDF) on 26 May 1990 by Ni John Fru Ndi. The gunning down of unarmed civilians by the State military power being indicative of the resistance towards changing the existing political status quo of a few lording it over the majority.

Though political pluralism reigns in Cameroon after the creation of the SDF has emerged as an envy of war tom states, much has yet to be done to institutionalize and legalize the various institutions to reflect the state of political pluralism in the country. By all standards, Cameroon is still a one party-party state in disguise. It is still governed by the dictates and structures of authoritarian regime form - the captivity of the legislature, judiciary and bureaucracy by a powerful presidency which treats the other branches of government as an offspring of a political party machinery - CNU/CPDM property. What is evident is that development wisdom is no longer lodged in government bureaucracies but in local communities and institutions - in short, in the people, that is, where indigenous knowledge and popular participation occupy increasing prominence in the development. The captivity of the Cameroon civil society was the result of two integrated fundamentals; (i) the institutionalization of a monolithic political system in 1966, and (ii) the abolishment of the federal governance system in 1972 which intensified centralization and the co-optation of the English 
speaking sector in to the ambit of French centralized system. As a result, civil society went into slumber and Cameroon degenerated into what has been until now an authoritarian state that violated ail aspects of fundamental human rights and liberties. There is now an emerging vibrant civil society that could challenged the state in 1992 through the politics of "ghost towns" which helped in crippling the economic base of the country as well as in weakening the political structure and legitimacy of the party, state, and government. Taking the bull by the horn, the path for a return to a democratic governance system was gradually being formed. A new vibrant society is now in the making.

So far, the Cameroon civil society has been confronted with problems of political apathy, lack of organisation, a sense of direction and leadership. Generally democracy requires organisation. Organisations requires an interest in public affair (see Hydén 1998: 18). The failure of the nation-state to be the liberator of the people since independence and particularly from the 1990s prompted Cameroonians to adopt a cynical and distrustful attitude towards politics and the state.

21 Even though the Second Republic under Paul Biya (1987) produced Communal Liberalism, advocating for change, the damage had already been done as the issues or slogan of "rigor, moralization and democratization" were more or less deplored to tarnish the image of the First republic rather than put into action the true meanings of the above concepts. The misuse of these concepts became a part of the system, and used as a false passport for personal accumulation and of bleeding the nation to death. An interesting analysis is given by Bayart (1993) in what he terms "the politics of the belly". Echoing on the issue, the Le Messager newspaper (16 March 1992) wrote :

"A sentiment of disappointment gradually replaced that of hope as it dawned on Cameroonians that qualification, competence and merit was the preserve of the President's tribesmen. Slowly, but surely, they started taking over all strategic appointments once held by people of different tribal horizons. In an expansive and greatly populated divisions like Noun, disappointment soon made way for bitterness as the division was suddenly taken over by the Betis - SDO, five D.0s, three (chef) police officers, medical officers, chief magistrates, prison superintendents etc. The story was the same in every other province of Cameroon as a top civil servant once inadvertently confirmed on T.V. by saying that thirty seven of the forty nine divisions were headed by Betis."

The situation has not abated. Rather, it is on the increase for every appointment made be it in the private or public sector. Less than a decade in office, civil society could easily access the achievements of the New Deal Government (NDG) with that of the predecessor. The record of the NDG remains pathetic in many aspects countless catastrophes, salary cuts disasters, decline in living standards, so salary increase for the past 18 years, embezzlement and hundreds of other cases. Takoungang and others (Takoungang \& Krieger 1998) point how much capital was siphoned from state coffers within a year and how tribalism was institutionalized in the public and private sectors with regards to appointments into key administrative posts. These acts were enough to pacify civil society or to induce it to greater actions for change. Or what Diamond (1994: 4-17) sees as civil society being "the realm of organized social life" standing between individuals and political institutions of representation." 
society in Cameroon had to be vibrant in order to create a new political agenda and landscape in respect to what Diamond sees as civil society strengthening the democratic process in respect of :

- Containing the power of the state through public scrutiny ;

- stimulating political participation by citizen ;

- developing such democratic norms as tolerance and compromise ;

- creating ways of articulating, aggregating and representing interest outside political parties, especially at the local level ;

- mitigating conflict through cross-cutting or overlapping interests ;

- recruiting and training political leaders ;

- questioning and reforming existing democratic institutions and procedures;

- disseminating information.

Civil society revolt against the state and the ruling CPDM, known in a way as "chop people" (dem moni), could be seen through the institutionalization of the ghost town politics which crippled the economy as well as weakened and challenged the authority and legitimacy of the state. State responses in the wake of establishing its lost legitimacy came from the state of emergency and other tough measures clamped on the society and in particular the province and house of the leader of the SDF ; the arrest of SDF supporters and sympathises, the seizure and destruction of peoples property by the forces of law, confinement of opposition supporters and worse still, the killing of innocent unarmed citizens.

Analysing the situation, Philip Burham (1996:160), Takougang \& Krieger (1998: 8) note that "The Cameroon state has not descended to the level of the Zairois state" and "what Cameroonians have seen since 1990 called to crise / the crisis must be made clear for those who do not yet recognize its depth and duration". Michael Schatzberg $(1986: 14)$ likened Cameroon's state apparatus to the African domestic community, the paternal premises of nurturance satistying a "complex and largely unarticulated moral matrix of legitimate governance". He also adds that in Cameroon "fathers" in the presidency and high offices fattened up on "sons left with little nourishment now, or prospects in the future". Government legitimacy was gone, and would have to be restored before any democratization could take place.

Beyond being voluntary, self-generating, autonomous, and rule abiding, civil society organisations played what could be termed "parochial society" - in several respects. Fundamental here was the part that civil society played a balancing role - i.e. balancing state's power in respect of (i) breaking state monopoly over resources mobilization and allocation, and (ii) decentralizing developmental responsibilities to local self-generating institutions.

The events of 26th May 1990 triggered developments within the two framework. First the credibility hegemony and legitimacy of the ruling regime and party was described and seriously challenged. Government response was to initiate token adjustments to apace the situation and re-establish lost confidence - for example, the idea of a national conference or "grand debate" to address the political crisis, the opening up of the political space - political pluralism with the result of overl50 political parties registered; movements towards the liberalization of press freedom, conducting multi-party elections, even though these elections have not been devoid of fraud and other electoral malpractices to ensure the continuation in power of the old regime. 
The 1992 parliamentary and presidential elections marked a new turning point in the political annals of Cameroon. For the first time since the creation of the single-party (1966) and the abolition of the federal system (1972), the National Assembly (1992) no longer was a hand clapping and captive body per se. It took a new dimension, even if only token - that of a competitive institution with more than one political party. The new parliament saw the entry of the National Union for Democracy and Progress (NUDP or UNDP) emerging as the major opposition party with 68 seats, the UPC (Cameroon's oldest political party) with 18 seats ; the MDR 6 seats and the ruling CPDM 78 seats. Through political manipulation, the CPDM captured the UPC and MDR as well as a break away fraction of the NUDP/UNDP into the government.

The major opposition party (SDF) boycotted the 1992 parliamentary elections on grounds of the non-establishment of an independent electoral commission (IEC) ; and the failure by the government to set the rules of the games to ensure free and fair elections. However the party contested the 1992 Presidential elections which is allegedly claimed to have won but victory stolen from Ni John Fru Ndi. A number of observers maintained that the elections was fraudulently won (see among others Clark \& Gardinier 1997 ; NDI 1993 ; Takougang \& Krieger 1998 ; Wongibe 1991).

In 1997 the SDF participated in the parliamentary elections with the results and consequences of the party being robbed of victory. Observers reports are clear on this as well (Takougang \& Krieger 1998 ; NDIIA 1992 amongst others). The 1997 presidential elections was boycotted by the SDF following the events and circumstance surrounding the parliamentary elections. The controversial and final results place the SDF with 43 seats, the UNDP with 13, UDC 5, MDR 1, MJLC 1, and UPC 1 out of total of 180 parliamentary seats with the ruling CPDM capturing the rest.

Since 1990, the Cameroon civil society has facilitated the introduction and constitutionalization of power, and a gradual return to democratic regime form in which civil and political liberties are now, somehow guaranteed but with the sorrowful results of the absence of public accountability of those in office not effectively assured.

The failure of the state as a liberator of the people propelled civil society's efforts towards the liberalization and privatization of the economy in order to reduce the dominant role of the state in development. The creation of the SDF and the emergence of many mushroom parties backed by civil society played a catalytic role in the democratization transition process though Cameroon still has a long road to travel to genuine democratic rules and practices. The fact remains that a State-led strategy of development and democratization has been given new dimensions - the results of the failure of civilian-authoritarian regime form to promote development or bring back economic growth to the level of the immediate post-independence years has reinforced the demands for regime change and transition.

The political landscape in Cameroon today is totally different from that of the 1980s and early 1990s. The past decade has witnessed remarkable progress for democracy and economic reforms. With the collapse of communism, democracy has reached or touched every region of the world for the first time in history, and in the words of Huntington (1992: 8) become "the only legitimate and viable alternative to an authoritarian regime of any kind".

Civil society in Cameroon has been a cause and consequence of this process - the construction of a new political formula for the country, and even though the 
emergence of a genuine democratic governments has yet to see daylight in Cameroon, the first step has been taken in that direction. The move towards democracy provides the much needed political space to manufacture new forms of governance whereby social capital can be constructed.

The challenges

A democratic culture of participation, moderation, accommodation, tolerance, and restraint is critical to the consolidation and long-term stability of democracy. Civil society has a role to play towards the realization of such goals. Here lies the challenges confronting civil society - how to adopt a confrontational approach towards the state i.e. defending individual liberties against the state and upholding the principles of civil and political rights of the individuals at any price. It could be argued that taking such an uncompromising approach towards the state may undercut the overall objective of building social capital and strengthening civil society. Hadenius \& Uggla (1996) argue that such a position is also fraught with its own risks.

The other is that of balancing state's power, how the state can be made to loosen its grip over society. As earlier indicated this may involve (i) reducing state monopoly over resources mobilization and allocation and (ii) decentralizing developmental responsibilities to local self-governing institutions. This strategy entails a parallel devolution of political authority to local government institutions as well as to grassroots in order to enhance the chances of influencing public policy-making.

What is vital is the (in) compatibility of political and economic liberalization. Both politics and economics constitute complimentary processes with each impacting on the other in many and varied ways. The challenge confronting civil society in Cameroon is that the Cameroon government has degenerated into a system of personal rule, strongly influenced and supported by ethnic constellations and patronage networks since the country between (1996-1990) lacked a strong and coherent civil society necessary to hold the state accountable for its actions.

Civil society during this period was co-opted and coerced into the ruling organ of the party and state machinery. Civil society became captive, weak and constituted nothing short of a hand clapping or praise singing body that did not reflect the interests of the people, but played to the tones of the government and its offspring - the ruling CNU-CPDM hegemony as well as to please exploitative foreign capital interests.

The challenge therefore, is for civil society to reverse existing trends - that of the regime displaying rent-seeking, corrupt and authoritarian behaviour, or creating and establishing as well as institutionalizing an environment that can hardly support a dynamic economy and democratic governance. The other factor is to regain and institutionalise its lost or fast diminishing hegemony - i.e. establishing the enabling environment necessary to allow greater political and democratic participation.

Creating the necessary political agenda that encourages or inform people who had gone into slumber because of the dark years (1966-1990) and who until after 1990 still have little or no experience with liberal democratic structures of governance. In short, to institutionalize "popular participation and responsibility." Presently, current rhetoric concepts of "popular participation" avoids the people most affected - the grassroots and the suffering masses - the rich have jumped on the bandwagon to continue to take away from the "have-nots". For example, the newspaper, Le Messager of 9 June 1992 wrote : 


\begin{abstract}
"It must be noted that Mr Biya's desire to pander to the needs of his clansmen had women opened the floodgates of the fraud which manifested itself in capital flight, embezzlement, the collapse of once viable state parastatals such as Cameroon, Societé camerounaise de banque (SCB), National Produce Marketing Board (NPME) $\mathrm{BIAO}$ and others. The horrible truth that soon became apparent was the fact that the President of the Republic could no longer control his own people. He could not even control his wife who depleted one of the banks to build villas, a palace, plantations and other businesses for the Presidential couple and their numerous relations."
\end{abstract}

41 So far, the policy and slogan of popular participation ignores an important stream of democratic theory traceable to Aristotle, Jean Jacques Rousseau, John Stuart Mill ; Alexis de Tocqueville and a host of others on the prescription that participation involves "a containing inter-relationship between the working institutions and the psychological qualities and attitudes of individuals interacting with them" (Paterman $1970: 22)$.

Rephrased in another way, participation involves not just policies but equally the development of social and political capacities of each individual establishing the theme "popular participation". Schmitz (1992) states that "support for democratic participation therefore should mean empowering the people to make their own decisions not engineering the forms of good governance which other elites are expected to undertake".

Civil society has to seriously deconstruct existing power structures of the regime and to put in place an alternative strategy that is more authentically democratic. The new agenda of civil society should be one of democratizing existing authoritarian structures. To begin with, this should involve, accepting that development is more than economic growth and institutional structures of governance. Or what Tim Broadhead (1993) notes, "a process of realizing potential, maximizing choices and allowing people thereby to become more fully human".

The state of political impasse and urban violence, ethnic cleansing that ravaged Cameroon at the start of the democratization process in 1990 is traceable to the absence of views expressed by Broadhead. Civil society was denied its rights - people were prevented from participating and sharing in the democratic and economic liberalization process. The wealth of the nation became the prerogative of a selected few who felt they were doing the nation a favour by constructing roads or providing social services and other amenities to the society. In reality, funds for these development projects being the sweat of the suffering masses hijacked by the governing elites as their personal properties. Selfish interest has replaced the common interest, destroying the sense of belonging amongst the excluded group of people within the society.

45 A state-civil society accord has to be established for the country to move forward. This requires the provision for increased opportunities for greater popular participation, the re-evaluation of existing policy strategies and the role of dominant players who for personal reasons and self-interests continue to stifle national development and the emergence of genuine democracy within the society.

46 It is imperative that the entire structure of the existing development agenda and political calendar of the ruling regime be re-evaluated and reconstructed to reflect the political, economic and social aspirations of the people, not that of a selected few who 
have created an "isolated island of privileges" and continue to bleed the nation to destruction and death.

Now that some form of quasi-political pluralism and media freedom or liberty is attained, what impact has this on society? In short, has anything changed from the days of a captive, hand clapping and weak parliament to that of an institution sharing power with other branches of the government, especially the executive? Who participates, when, how and to what effect in the emerging new political dispensation of the societies enormously important to the depth and durability of the democratization of the nation.

By and large, the new political dispensation should imply removing the obstacles (economic, gender, racial, cultural etc.) from existing power structures to persons and communities developing the capacity for democratic governance. So far this is not the case. What continues to exist is the total absence of the necessary political mechanism to aid the transition from authoritarian to democratic governance. Incumbent power brokers continue to thwart such mechanism to prolong their stay in power - to maintain existing status quo even in the wake of a new political wind blowing across the continent.

Existing power structures continue to perpetuate the diffusion of ideologies that entrenches the grip on the state, on the structures established immediately after the attainment of political independence. Largely also because the developed democracies and the Bretton Woods Financial Institutions for all their invocation of politically correct language, have shown that they are not ready to surrender control over agenda setting to local democratic forces. Western dominated development agenda constantly defines the parameters of development and behaviour in Cameroon as well as in other countries under transition. France takes the lead in articulating and setting the pace for such behaviour. France remains the principal agent for "delivering development" to Cameroon. Here we find French-Western and internal ideologies of the ruling elites converge to destroying and placing the society in a state of perpetual poverty and underdevelopment.

Bratton \& Van de Walle (1992 : 420) correctly argue that the "diffusionist and structural interpretations partly explain recent political events in Africa in the course of transition, the major participants and the dominant influences in every case have been national". Who articulates policy strategies and measures for the destruction and not constructing of the society? In all the development trajectories and strategies of post-colonial Cameroon have been either a reflection of, or a reaction to the agenda set by the strongest international players. Cameroon became vulnerable following the collapse of the First Republic and to pressures exerted on the Second Republic by the very doings of those who control the New Deal Regime.

51 Flowing from the preceding paragraph is the challenge of civil society standing up to the forces of the international system. Admittedly, while the revival of civil society has received encouragement from the international community, the global impact has also been the down fall and weakening of civil society who for a number of reasons beg and dance to the calls of these international bodies like state governments have done all these years.

52 Civil society could gradually become a captive and weak instrument of external forces. The challenge is how to exert autonomy and independence towards its objectives. So far, the question is whether Cameroon can be devorced from its international and 
transnational connections and to resist the presence of dominant international financial actors? The challenges for civil society and for the overall survival of democratic governance in Cameroon is to understand the issues of global connectedness that the management of development and democracy in Cameroon will move toward more democratic and developmental connectedness when these issues are coherently appraised and incorporated into a common policy framework.

So far, the Cameroon Government under its present constituted leadership cannot provide that connectedness with the impact and consequences that the society suffers and trails behind in the democratization and economic liberalization processes. On top of that, the country's image keeps declining within the international arena as the leader of the nation has presented himself as an "absentee president" falling to be a participant in international arenas where and when it is necessary. Cameroon has adopted a policy strategy of keeping away from vital African and international fora.

Two recent events are worth mentioning in this context. First, the absence of the President at the swearing ceremony of the civilian elected President of Nigeria (29 May 1999); and the installation of South Africa's second democratically elected president (Thabo Mbeki replacing retiring ageing President Nelson Mandela on 16 June 1999) does not argue well for the international connectedness of Cameroon. To this could also be added absence from the OUA meeting in Zimbabwe to hand over the presidency of that organisation to the incoming president; absence from the last special OUA meeting in Tripoli to redefine a new code of conduct for the OAU at the dawn of a new millennium. The list is long. Let us contend ourselves with those mentioned here.

The above mentioned cases presents Africa's best attempts at embracing the democratization process and shift from authoritarian governance system. Could absence be interpreted as a phobia in countries that presidents have been democratically elected in a freely and fairly conducted electoral process? Could absence be interpreted as a sign of guilt? Or should this be seen as the country's leadership being allergic to genuine transformation to good governance? What ever the situation and postulations made, the scenario is clear; that the democratization process in Cameroon is a tailored one designed to meet the aspirations of those currently in power and not one of government by the people and for the people. Hence a new political and economic development agenda emerging from a rapprochement of the Cameroon people and a revitalized civil society is required to promote economic growth and democracy in the country. The state must be brought back from the current wondering expeditions to that of national reconstruction, economic and political progress to counter act the negative effects of globalization disparity and dwindling welfare gap both between and within the country.

56 The major challenge for the government or state is that of regaining trust. For the past two decades, the state has lost credibility and legitimacy. The issue is to regain lost trust and confidence. Regaining the trust of the people - civil society requires at least, three major shifts by government leaders and others in authority.

- Responding to the citizenry (civil society) in its diverse formation;

- Finding and publicizing new examples of public stewardship ;

- Collaborating across traditional boundaries, whether of party, class, geography, or perceived interests.

57 The failure of government to fulfil its obligation of the social contract - irregular payment of salaries and other debts owed the people, the state of insecurity, 
non-functioning of public services and utilities, the total absence of the rule of law, armed forces pursuit and arrest of innocent citizens and their collaboration with criminals and other bandits, dismissal of employers for not toeing the ideals of the ruling party, breakdown in law and order, the politics of fanning ethnic cleansing and conflict all amount to a bridge of trust on the part of the State.

Clearly, the challenge to regain trust in the Cameroon society is immense. the State has to work harder more than ever before to reinstate lost confidence and regain legality and legitimacy with civil society. A cord of peace and reconciliation must be brokered between the State and civil society. The wind of political change blowing across the continent implies that a recovery of civil society is taking place in Cameroon. That wind of charge begins with the resurgence of local voluntary efforts of citizens banding together to solve their common problems. When conditions are right, it moves forward to inject new life to the structures of government by creating and expanding arena of "civic governance". This happened on 26 May 1990. An event that has given a new political dimension to the country and which existing forces cannot hold back but make sure that the re-democratization train keeps moving forward and in the right direction.

On the other hand, government is not a bad public service vehicle; it is just an incomplete one. On top of that, it cannot do the job all by itself. Government lacks the necessary competence and other vital mechanisms - a key ingredient of civil society. That is why the marriage between the two is imperative for society to move in the right direction.

Since the ideals of democracy and civil society was floated in 1990, it is not by pure chances that participatory rapid appraisal (a methodology which allows people to have a greater say and control over the direction of their lives and which ensures that no one institution overpowers others) should also be taking hold in the country. This is simply in part a reaction to the many disappointments and failures in system of governance which Cameroonians have been subjected to that so much effort is going into finding ways to realize this idealism.

61 The challenge today, and henceforth, is to unite the various communities and fragments into finding and creating a connection between the State and citizens to reconstitute civil society as an inherent way forward to an endurable democratic governance and socio-economic development system.

Conclusion : surviving the $21^{\text {st }}$ century

62 The legacy of the dominant one-party politics and centralized bureaucratic set up is likely to persist stubbornly in endless petty and profound ways far deep into the new millennium. Breaking it requires intensive education and empowering of the victims of the system as well as equally re-educating the advocates of the system, and, of course, promoting dialogue between the various political and economic stake holders. Civil society associations in various ways have a crucial role to play in the process of political change, curbing political violence, limiting the politics of ethnic hegemony and cleansing through mobilization of all available societal resources (natural and human), mobilization of community participation and vigilance, and as well as adopting, articulating and aggregating a policy of reconciliation, consensus, dialogue and participation between the various contending political forces. 
Given the new level of political knowledge and democratic understanding amongst the widest segment of the population due to the many decades of the legalization of a dominant monolithic political system that excluded the politics of participation.

The mass media, has during the past half decade played the important role of awareness creation and education amongst the people. That effort should not be allowed to decline. Rather, all civic associations should join forces to advance the return to democratic governance and good management. This implies "reinventing government" where the entire governmental system and structure is made to "work better and cost less" (Troxel 1995 ; Osborne \& Gaebler 1992).

Throughout the continent (and Cameroon in particular), ordinary people are demanding a second independence; this time from the indigenous leadership whose social, industrial, economic and political mismanagement, together with brutal repression, have made mere survival all but impossible. There is an increased awareness among Cameroonians that the monopoly or power enjoyed by failed leadership has to be broken in order that power can be transferred to the people who have little to lose and much to gain; that is why demonstrations for democratization in Cameroon persisted in the 1990s in spite of repression, and will continue to do so ; and why civil society organizations have found a growing and reliable base in opposition Parties. The question of course, remains, for how long will belly politics reign?

The regime is very effective and efficient in spoil politics - of divide and rule. This it applied in 1992 which split the NUDP into two blocks. And of recent, the same strategy was adopted in splitting the SDF. However, it failed. The countervailing forces of the State should not be under estimated in the process of destabilizing opposition parties.

, the democracy movement and train for political reconstruction in Cameroon is a powerful objective, historical force as it continues to express the desire of the ordinary people to gain power and material improvement - quality living standards for all by the year 2010. There are indications that the desire for material improvement is fuelling the democratization process in Cameroon. This has far-reaching consequences. This implies, first that the feasibility of democratization will depend partly on the correlation of this process with better economic prospects. Second, the critical importance of the economic factor in the Cameroon democracy movement will mean a change of emphasis from abstract legal and political rights to social and economic rights ; from laissez-faire and the tolerance of economic inequality to the acceptance of considerable economic intervention in the market place in the interests of growth and redistribution of economic wealth.

Civil society is revitalising itself to playing a more fundamental role to further the course of economic and democratic liberalization. The creation of a democratic and development culture remains crucial and constitute the only way forward to building a vibrant and sustainable society. Cameroon is currently facing growing crisis in health care, welfare, unemployment, and many other critical issues. The resolution to these issues even though with a 8.9 percent increase in the 1999-2000 budget allocation. are not at all c1ear. Yet these Gordian knots form the stuff of the recovery of civil society in Cameroon. It is even more clear given the failure rate of the governance that they cannot be resolved in conventional terms and forms. They key in finding the way out is a return to civil society through the community and its citizens working together with the state. What this entails is that of civil society shifting the emphasis on government as "problem-solver" to the development of civic muscle and of local communities and 
institutions in the community contributing to creating a safer and enabling environment.

As of now, peace and tranquillity has so far reigned in Cameroon ; it is an envy of other states within the Central African Sub-region. Implying that a strong civil society in Cameroon can equally be a catalyst for radical changes - political and economic - in the sub-region. Now that the urgent challenges of breaking the back of the single party has passed, there are massive new requirements and challenges for civil society to intensify efforts in the re-democratization process. Democracy is more than the sum of its institutions. A healthy democracy depends in large part on the development of a civic culture. And culture here refers to the behaviours, practices and norms that define the ability of a people to govern themselves.

On the other hand, a single party or totalitarian system that was established in Cameroon between 1966 and 1990 encouraged a culture of passivity and apathy. Here the government moulded an obedient and docile citizenry. Thus the events of 26 May 1990, moved Cameroon. From the established state of totalitarianism to embracing democracy - that is creating a civic culture of a democratic society. A democratic society shaped by the freely chosen activities of individuals and groups for the common good.

71 Democracy has to be recreated in the context of the given realities and in political arrangements which fit the cultural context, but without sacrificing its values and inherent principles. In Cameroon this fit is likely to entail, among other things, a "consocietal" arrangement - the use of every ethnic group, social class, communities as the constituencies for representation. There is a need for the establishment of a highly yet representative decentralized system of government with equal emphasis on individual and communal rights. It has also to be understood that democracy in Cameroon is not something that will emerge from a rational blueprint; it must emerge from practical experiences and improvisation in the course of a hard struggle.

The process towards democracy and economic liberalization in Cameroon must be shaped by the singular reality that those whose democratic participation is at issue are the ordinary people of the country - the buy and sell group, the marginalized poor many are illiterate, and almost ail are poor; rural dwellers in an essentially pre-industrial and communal society. The international community most develop an obligation to support Cameroonian democratization process, not to support existing power structures focused to achieve only the democracy of alienation - power not to the people but to the existing powerful and exploitative classes.

73 Therefore, reconciliation, understanding, tolerance and mutual respect should be fostered and bridges constructed across the various economic, racial, ethnic, and political divide. In short, there is real hope for democracy and economic liberalization in Cameroon, the sub-region and the continent as long as a strong civil society is put in place and functions most appropriately within the framework outlined by Diamond. The fact remains that these multiple diverse pluralistic foundations of civil society that emerged in 1990 remain capable of forging, changing and reconstructing society and culture that can have a chain effect to redressing existing situation of authoritarian governance form in other parts of the Central African sub-region.

74 Finally, broad democratic legitimacy cannot be established unless democracy is able to work and function properly to improve the appalling conditions of the life of the vast majority of the marginalized population. A change in that direction can be realised 
provided we are all willing to see democracy and other changes triumph over authoritarianism and self-accumulation.

Civic organization can help the people realize they themselves are a resource. It creates a people of consciousness of their potential and their power as a group over the power holders. It enhances not only their political rights but of social and economic rights as well. Powerless people are not only powerless in a political sense but even more so in a socio-economic sense. The poor are often badly treated even by others like them or slightly better off. Empowering the poor through building their human capacity education constitute one major role of civil society in bringing progress in the society. The lack of education and skills makes it more difficult to help out their poverty and much effort and creative thinking is still needed in that direction.

The challenge of the next century will be to build democracy on a more human sc ale, ensure good management of both human and natural resources, and to expand the capacity of citizens for self-governance and public problem solving. Civil society enables people to be positive about the future. Being positive means creating sustainability. Sustainability is inevitable and the Cameroon population must not allow its cultural heritage to collapse, but to use culture as the framework and basis of development and in the sustainability of an emerging democracy and management.

Certain core values - inclusive participation and pluralism with honour - or trust, reciprocity, tolerance and inclusion constitute key concepts and values of eliciting inputs, participation and consensus embodied in the values of democracy and development. The act of developing these values is an act of civil society itself. Civil society must bring together peoples and groups at the various levels of society to identify core values and, sharpen their focus on what to aspire and assist in no small measure in realizing their aspirations - democratic governance and quality improvement in living standards.

The formation of Opposition Parties in the 1990s marked the beginning of a movement to reform the state. If repeated more broadly (i.e. the civic associations being on the progressive and reconciliatory offensive), this activity could catalyze a reformation movement for the institutionalization of a genuine democratization cultural process in Cameroon with effects far beyond the frontiers of the country. The promise of the post-single era rests largely on the potential of the country creating a strong, vibrant coherent and deeply rooted civic associations and institutions that mediate between the state and the people, the connective tissue of a democratic political culture. The best choice for Cameroon is to build a vibrant society for the sustainability of the nation-state.

Recommendations

- State-civil society harmony constitute a healthy sign for the growth of authentic democracy.

- Civil society or organizations are crucial instruments for democratic change and socialization because they functions as continuous instruments of participation and mobilization.

- Civil society contributes to the development of democratic culture in many ways which can be used by the state for awareness creation. The more pluralistic and coherent civil society is the more it benefits democracy.

- The State must bear its responsibility of ensuring balanced development and providing the needs of society equitably. 
- Civil society is never constructed or consolidated by ignoring others or by shouting them down.

- The legitimacy and authority of the state is more enhanced through a transparent, accountable, participatory regime form.

- Politics and economics are inherently linked and progress in one requires the support or progress in the other.

- There is an urgent need for "reinventing government" in Cameroon and to ensure "total quality management" as instruments for moving the country in the right path of sustainable development.

- Cameroonians must articulate and aggregate policies that fight against ethnic disparity and other dishumanizing corollaries, and put in place mechanisms for living together as a diverse people in a one and indivisible Cameroon village - this constitute a serious challenge to be resolved.

- There is also the urgent need for reinventing citizenship - ensuring shared values that stress a balance between rights and responsibilities of citizens - democracy being "of the people by the people, for the people" in the words of Lincoln, and not against the people.

- Democracy itself guarantees nothing. It offers instead the opportunity to succeed as well as the risk of failure. Yet building on Thomas Jefferson's shrewd phrase ; the promise of democracy is "life, liberty and the pursuit of happiness".

- Government of and by the people implies that the citizens of a democratic society share in its benefits and in its burdens. And of course, must take the responsibility for the failure and fate of the state - hence, a country gets the government it deserves. The challenge is for civil society to work towards a better governance system.

\section{BIBLIOGRAPHY}

Bayart, J.-F. 1989. "Cameroon". In Donald Cruise et al. (eds.) Comtemporary West African States, Cambridge, Cambridge University Press.

Bayart, J.-F. 1993. The Slate in Africa : The Politics of the Belly. New York \& London : Longman.

Biya, P. 1987. Communal Liberalism. London : Macmillan Publishers.

Bratton, M. \& Van de Walle N. 1992. "Popular Protest and Political Reforms in Africa". Comparative Politics 24.

Broahead, T. 1993. "Applying Lessons from the South in the North". Synergy 5.

Burham, P. 1996. The Politics of Cultural Difference in Northern Cameroon. Edinburg : Edinburgh University Press.

Clark, J.F. \& Gardinier D.E. 1997. Political Reform in Francophone Africa. Boulder : Westview Press.

Diamond, L. 1994. "Toward Democratic Consolidation". Journal of Democracy 5 (3).

Forje, J.W. 1981. The One and Indivisible Cameroon : Political Integration and Socio-economic Development in a Fragmented Society. Lund : Lund University Press. 
Forje, J.W. forthcoming. Cameroon Without Poverty. Yaoundé : CARAD.

Fru Ndi, J. 1993. General Policy Address to the Second Ordinary Convention of the Social Democratic Front. Bafoussam-West Province, Cameroon Republic.

Fru Ndi, J. 1999. General Policy Address to the Fifth Ordinary Convention of the Social Democratic Front, 22 April 1999. Yaoundé, Cameroon Republic.

Hedenius, A. \& Uggla F. 1996. "Making Civil Society Work". In : Hadenius, A. (ed.) Democracy's Victory and Crisis, London, Cambridge University Press.

Huntington, S. 1992. The Third Wave. Oklahoma University Press.

Hydén, G. 1998. "Building Civil Society at the Turn of the Millennium". In : Burbridge, 1. (ed.) Beyond Prince and Merchant - Citizen Participation and the Rise of Civil Society, New York, Pact Publications.

Monga, C. 1996. The Anthropology of Anger. Civil Society and Democracy in Africa. Boulder : Lynne Rienner Publishers.

National Democratic Institute for International Affairs (NBIIA) 1993. An Assessment of the October 11, 1992 Election in Cameroon. Washington DC.

National Democratic Institute for International Affairs (NDIIA) 1992. Declaration : Post-Electoral Preliminaries, 14 October 1992. Washington. DC.

Osborne, D. \& Gaebler T. 1992. Reinventing Government. Reading : Addison-Wesley.

Paterman, C. 1970. Participation and Democratic Theory. Cambridge : Cambridge University Press.

Republic of Cameroon 1993. Preliminary Draft Constitution (the "Owona Constitution"). Technical Committee on Constitutional Matters, May 17, 1993.

Republic of Cameroon 1995. Proposal of the President of the Republic for Constitutional Reform (the "Biya Constitution"). Yaoundé : Consultative Committee on Constitutional Reform, December 15,1994.

Schatzberg, M. 1986. "The Metaphors of Father and Family". In : Zartman, W. et al. (eds.) The Political Economy of Cameroon, New York, Praeger.

Schatzberg, M. 1993. "Power, Legitimacy and Democratization in Africa". Africa 63 (4) : 445-461.

Schmitz, G. 1992. "Why Words Matter : Some Thoughts on the New Development Agenda". Paper presented at the Annual Meeting of the Canadian Association in the Study of International Development. June 4, 1992, Charlottetown.

Takougang, J. \& Krieger M. 1993. "The Post Ahidjo Era in Cameroon : Continuity and Change". Journal of Third World Studies X (2) : 268-302.

Takougang, J. \& Krieger M. 1998. African State and Society in the 1990s: Cameroon 's Political Crossroads. Boulder : Westview Press.

Takougang, J. \& Krieger, M. 1997. "Cameroon : Biya and Incremental Reform". In : Clark, J.F. et al. (eds.) Political Reform in Francophone Africa, Boulder, Westview Press.

Troxel, J.P. 1995. Government Works : Profiles of People Making a Difference. Alexandria : Miles Rive Press.

Wongibe, E. 1991. The Social Democratic Front and the Thorny Road to Social Justice. Bamenda, Cameroon Republic. 
World Bank 1995. Cameroon : Diversity, Growth, and Poverty Reduction. Report No. 13167-CM, April 4, 1995. Washington De. World Bank.

\section{AUTHOR}

JOHN W. FORJE

Senior Research Officer and Lecturer. Department of Political Science, University of Yaounde II - SOA. Ministry of Scientific and Technical Research, Cameroon. PO Box 13429 Yaounde (Cameroon). Tel : +237-231825,239479; Fax : +237-226262, 226263, 231825 ; 217470. 